Japanese Journal of Transfusion Medicine, Vol. 44. No. 4 44(4) : 528-531, 1998

\title{
II. 教育講演：輸血医学「どこまで」シリーズ
}

1）血液製剂への放射線照射…どこまで行なうべきか

千葉大学医学部附属病院輸血部

浅 井 隆 善

\section{はじめに}

日本輸血学会からの輸血による GVHD 予防のため の血液に対する放射線照射ガイドライン I, II, IIIの 提示, 平成 8 年の輸血用血液による輸血後 GVHD に 関する緊急安全性情報の発表により, 予防強化が呼び かけられているにもかかわらず, その後も輸血後 GVHD の発症が続いている. 適正輸血や同種血輸血 の回避以外では最も有効な予防法と考えられている放 射線照射について, 有効な予防効果を得るために, ど こまで輸血用血液に照射を行なうべきか考察する.

\section{患者におけるリスク}

Hathaway らの報告以来輸血後 GVHD は重度の免 疫不全状態の患者に発症する特殊な合併症と考えられ ていた ${ }^{11}$. 従って, 先天性免疫不全や骨髄移植後, 及び 新生児等はその基礎疾患自体が高リスクと考えられて いる.しかし，わが国では背景に明らかな免疫不全の ない患者でも発症が多くみられ，この原因の一つとし て, 患者と供血者との HLA が一方向適合となり供血 者リンパ球が患者体内に生着する事が考えられてい る.このことと同時に, 心臓血管手術では新鮮血の使 用と院内採血による血縁者からの輸血が要因とされて いる. また, 癌の手術での発症も多く報告されている が, 発症に影響する因子の一つとして担癌状態におけ る免疫能の低下が懸念されている. その他, 最近の発 症例ではこれらの高リスク疾患以外でも発症が認めら れ, それらの患者の共通点として, 大量出血や重篤な 外傷が挙げられる.さらには, 確認された輸血後 GVHD の約 $80 \%$ 以上が 65 歳以上の患者であり, 高齢 も一つのリスクではないかと考えられている. 従って これらのリスクを伴った輸血に際しては輸血用血液に 放射線照射を行い発症の予防をすべきである.

このように，リスクの高い疾患・患者は経験的にリ ストアップされて, それらのいくつかは理論的にも発 症しやすい条件を伴っていたことがが見いだされてき ている.しかし，その発症メカニズムの全てが解明さ れたわけではなく, 未だ未知の要因が関与している可
能性が残されている.

\section{血液におけるリスク}

GVHD の機序を考えると, 供血者リンパ球の活性 が高いほど発症しやすく, 即ち採血後保存期間の短い 血液ほど GVHDのリスクが高いと考えられる。輸血 後 GVHD は旧くは術後紅皮症と称されていたが, 当 時は枕元輸血も行なわれていたと考えられ, 当日新鮮 血の輸血というリスクの高い輸血が行なわれていた背 景でこのような疾患概念が提唱されたものと推測され る.その後の発症例をみても新鮮血輸血の症例での発 症が多く, 理論的にも経験的にも新鮮な血液ほど輸血 後 GVHD 発症のリスクが高い.

では, リスクの高い血液とはどの程度までの新しさ を考えればよいのであろうか. $4{ }^{\circ} \mathrm{C}$ 保存ではリンパ球 は徐々に活性を失って死滅し, 保存期間が長くなるに つれて輸血後 GVHD の発症の可能性は低下してく る. 実験的には $4{ }^{\circ} \mathrm{C}$ 保存のみで免疫応答能がかなり低 下する事が確認されているが，どの程度まで低下すれ ば発症の危険がないかとの実験的な確認は成されてい ない.むしろ経験的に, 最も保存期間の長い血液で は, 採血後13日経過した血液の輸血で輸血後 GVHD 発症が確認されている. 従って, 採血後約 2 週間を目 処にしてそれより新しい血液では輸血後 GVHD 発症 の危険性があると考えべきである.

また, 輸注されるリンパ球の数が多いほど発症しや すいことも理論的に考えられる. 白血球除去フィル ターの性能が近年急速に進歩し, 白血球除去による輸 血後 GVHD 発症の予防も期待された時期があった が, 白血球除去フィルター使用後にも発症が報告さ れ2), その後も, 輸血後 GVHD が確認された19例のう ち 4 例は白血球除去フィルターを使用していたことが 判明している. 従って, 現在のところ, 輸血後 GVHD 発症予防には白血球除去フィルター使用だけ では不確実であるとされている。

輸血後 GVHD を発症し得る白血球を含んだ血液製 剤は新鮮凍結血漿を除く赤血球製剤，血小板製剂の全 
てであり，新鮮液状血漿での発症も報告されているの で注意が必要である。

\section{HLA 一方向適合}

患者と HLA 一方向適合となる血液は，輸血後に供 血者リンパ球が早期に排除されず一定時間は生着する ことになる.その後, 患者 HLA 抗原の刺激を受けた供 血者りンパ球は免疫応答により急速に分裂増殖し，充 分な数に増えた後に患者組織を傷害し GVHD が成立 すると考えられている，実際に，日赤中央センターで 確認された輸血後 GVHD 発症例で, 先天性重症免疫 不全の患者以外の確認した全ての患者が供血者と HLA 一方向適合となっていると聴いている．血縁者 間の輸血ではハプロタイプを共有する可能性が高く,

この HLA 一方向適合に成る可能性が高い. 院内採血 による当日新鮮血輸血は, 血液中のリンパ球活性が高 いことと同時にこの HLA 一方向適合となる可能性が 高いことでも高リスクである.

わが国では非血縁者間でも諸外国に比較して HLA 一方向適合になる確率は数百回に一回と高く，非血縁 者からの輸血と言えども放射線照射による予防が不用 とは考えにくい. しかし，輸血前に HLA 型を検査し HLA 一方向適合の有無を確認することは, 検査に要 する時間や，経済的負担を考慮しても現実的ではな い. 従って，HLA一方向適合になる可能性を想定し て，リスクの高い輸血について血液照射による予防を 行なうことが実際的で有効な手段と考えられる。

\section{発症予防の因子}

担癌患者や高齢者は免疫機能がある程度低下してい る可能性が考えられているが，これらの患者で輸血後 GVHD が多く発症している事実を考えると，この程度 の免疫機能の差が発症の予防に影響している可能性は 否定はできない。つまり，HLA一方向適合により， 供血者リンパ球が生着し, 免疫応答で急速な増殖をす るまでの一定時間に供血者リンパ球をある程度排除ま たは非活性化する機序が健常人に備わっているとすれ ば，担癌患者や高齢者ではこの機能が徐々に損なわれ てきていると推定されるが，このような機能の評価に ついては今後の研究に頼らざるを得ない.

輸血後 GVHD の発症は輸血量の多さには必ずしも 比例せず，むしろそれまで輸血歴のない初回輸血患者 で多い傾向が認められている。これは換言すれば輸血 歷のある患者では，輸血後 GVHD 発症に対して抑制 的に働く機序の存在が考えられる．事実，次のような 実験的事実が報告されている．先ず，頻回輸血患者の
代表的名疾患群である造血器腫瘍患者のリンパ球では APC（抗原提示細胞）を示す表面抗原が減少し，患者 の単核球は MLR (リンパ球混合反応) による刺激能が 低下していること ${ }^{3)}$ ，また，頻回輸血患者では抗イ ディオタイプ抗体が輸血後 GVHD を起こしにくくし ていることが報告されている4).そして，輸血ドナー の患者に対する MLR を患者リンパ球が抑制するこ と ${ }^{5)}$,さらには, マウスでは CD8陽性細胞と NK 細胞が 輸血後 GVHD の発症を抑制していることが報告され ている ${ }^{6)}$.これらの事実は, 将来の治療応用への発展 を期待させるが，未だその可能性は未知数である，ま た，放射線照射の必要性を，これらの機能検査で予知 することの期待ももたれるが，これも輸血業務への応 用はまだ未知数である。しかし，これらは初回輸血患 者は輸血後 GVHD のリスクが高いことを示唆してい るのは事実のようである.

\section{放射線照射量}

輸血後 GVHD の発症予防に必要な照射量は日本輸 血学会のガイドラインでは血液の何れの部分において も15〜50Gy の条件を満たすことを推奨している．諸 外国をみてみると, 英国では25Gy 以上7), 米国の FDA や AABB では中心線量が25Gy 以上で何れの部分も $15 \mathrm{~Gy}$ 以上 $^{7) 8)}$ ，オーストラリアのクインズランド州で は中心線量が25Gy を基準にしている 線の至適照射線量は $30 \mathrm{~Gy}$ との報告論文も見受けられ $3^{10)}$. 何れも表現は若干異なるが，照射野の何れの部 分も $15 \mathrm{~Gy}$ 以上にするためには，照射装置によって異 なるものの, 中心線量は通常 $25 \mathrm{~Gy}$ 前後にする必要が あるので，諸外国の基準とわが国の基準とは大きく矛 盾はしないと考えている.

放射線照射を行なった血液を輸血したにもかかわら ず，輸血後 GVHD を発症した症例が数例報告されて (る ${ }^{11) ~ 13)}$. これらは何れも造血器腫瘍の患者で強力 な化学療法あるいは骨髄移植に関連した時期に発症し ており，一例では照射野の一部が15Gyに達していな かった可能性を考察している ${ }^{111}$. 従って，重度の免疫 不全が背景にある場合には照射量の工夫が必要な場合 が想定されるが，背景に明らかな免疫不全のない外科 手術患者では, 何れの部分も 15 50Gy の範囲で照射 することの準拠が先決と考えられる.

\section{照射施行への障壁}

これまで輸血後 GVHD の発症を充分に予防できて いないのは，一つには本合併症の理解不足が挙げられ る. 予後の極めて悪いことの認識不足と，また滅多に 
遭遇しない特殊な合併症と軽視されていたことが考え られる.実際の発症頻度は正確には分かっていないが, 昭和62年の日本輸血学会 GVHD 調查研究会の胸部外 科手術を中心とした第一次調查では658.9件に 1 回の 頻度で出現しており, 日赤中央血液センター発行の輸 血情報では 16 万回の輸血に 1 回の頻度とされている. また， 1 施設の集計では，東京女子医大の 1 万本の輸 血に0.168回 (一部の疾患の輸血に照射をして予防を開 始した後は 1 万本に 0.077 回 ${ }^{14)}$, また我々の施設では 主治医の指示により照射を行なっていたが 1 万本の輸 血で0.741例の発症があった.これらの発症頻度の差 は各病院における輸血方法や，予防体制が異なること も考えられるが, 確定診断に至らずに看過された患者 のいる可能性も懸念される.

予防が充分に行なわれないことの原因のもう一つに は放射線照射の血液に対する影響も考えられる．現在 明らかなのは, 照射後血液では保存とともに上清のカ リウム濃度が上昇しやすいことが知られている，その ため照射後長期に保存できないとの懸念から, 放射線 照射を控える傾向も認められる，採血翌日に $15 \mathrm{~Gy}$ 照 射した MAP 加赤血球では使用期限最終日の 21 日目で は上清のカリウム濃度は約 $55 \mathrm{mEq} / \mathrm{L}$ になるが, これ は 1 単位製剤 1 バッグ全体の上清中のカリウムの総量 では約 $3 \mathrm{mEq}$ となり, 通常の患者では維持輸液程度の 輸注速度であれば問題はないと考える.しかし，新生 児, 未熟児, 腎不全患者, 急速大量輸血患者ではカリ ウムの輸注速度が過剩にならないように注意を要す る.

\section{おわりに}

放射線照射の影響については, 発癌の可能性や, 未 知ウイルスの突然変異の可能性なども考えられるが, その確率はきわめて低いと推定されている。しかし, これだけ多くの規模で血液に放射線照射を行なうこと は，世界でも経験はないので，これからも，血液に対 する放射線照射の影響については長期的な評価が必要 と考えられている.

何れにしても，未だすべての適応に対して血液照射 が行なわれるにはいたっていないと思われ，ガイドラ インで示されたリスクの高い輸血に対して照射を行な い, 輸血後 GVHD が有効に予防されることを期待し たい.

\section{文 献}

1) Hathaway, W.E., Githens, JH., Blackburn, W. R., Fulginiti, V., Kempe, CH.: Aplastic ane- mia, histiocytosis and erythema in immunologically deficient children. N. Engl. J. Med., 273 : 953-958, 1965.

2) Akahoshi, M., Takanashi, M., Masuda, M., Yamashita, H., Hidano, A., Hasegawa, K., Kasajima, T., Shimizu, M., Motoji, T., Oshimi, K., Mizoguchi, H.: A case of transfusionassociated graft-versus-host disease not prevented by white cell-reduction filters. Transfusion, 32: 169-172, 1992.

3）池田久實，三谷孝子，芳賀寛史，関本達也，小島 聰, 関口定美, 直原 徹, 河野通史, 平田 哲, 島 本悦宏, 久保田勝秀: 造血器腫場患者のリンパ球 応答性. 輸血後 GVHD，その現状と対策（関口定 美編集)。エフ・コピント・富士書院発行，札幌， 1998, 42-51.

4) Nishimura, M., Sakai, K., Akaza, T., Mitomi, Y., Nieda, M., Minami, M., Juji, T.: Antiidiotype antibody to T-cell receptor in multiply transfused patients may play a role in resistance to GVHD. Transfusion, 32: 719-728, 1992.

5) van. der. Mast, B.J., Hornstra, N., Ruigrock, M. B., Claas, FHJ., van. Rood, J.J., Lagaaij, E.L. : Transfusion-associated graft-versus-host disease in immunocompetent patients : a self protective mechanism. Lancet, 343 : 753-57, 1994.

6) Fast, L.D., Valeri, CR., Crowley, J.P.: Immune responce to MHC homozygous lymphoid cells in murine $\mathrm{F} 1$ hybrid recipients: implications for TA-GVHD. Blood, 86 : 3090-3096, 1995.

7) Williamson, L.M. : Guidelines on gamma irradiation of blood components for the prevention of transfusion-asociated graft-versus-host disease. 輸血後 GVHD，その現状と対策（関口定美 編集).エフ・コピント・富士書院発行, 札幌, 1998, $165-184$.

8) Issues and transfusion of blood components; irradiation. 16th Standards for blood banks and transfusion services. American Association of Blood Banks, Maryland, 1994, 32-33.

9) Dennington, P.M.: Current indications for irradiation of blood products in Australia. 輸血 後 GVHD, その現状と対策（関口定美編集）. 工 フ・コピント・富士書院発行, 札幌, 1998, 187193.

10) Rosen, N.R., Weidner, J.G., Boldt, H.D., Rosen, D.S.: Prevention of transfusion-associated graft-versus-host disease: selection of an adequate dose of gamma radiation. Transfusion, $33:$ 125-127, 1992.

11) Lowethal, R.M., Challis, D.R., Griffiths, A.E., 
Chappel, R.A., Gouder, P.J.R.: Transfusionassociated graft-versus- host disease : report of an occurrence following the administration of irradiated blood. Transfusion, 33 : 524-529, 1993.

12) Drowski, W., Thibodeau, S., Truitt, R.L. Baxter-Lowe, L.A., Gorski, J., Jenkins, R., Gottschall, J., Ash, R.C.: Third-party-mediated graft rejection and graft-versus-host disease after T-cell-depleted bone marrow transplantation, as demonstrated by hypervariable DNA probes and HLA-DR polymorphism. Blood, 74 :
2285-2294, 1989.

13) Sproul, A.M., Charlmers, E.A., Mills, K.I., Burnett, A.K., Simpson, E. : Third party mediated graft rejection despite irradiation of blood products. British Journal of Haematology, 80 : 251-252, 1992.

14）岡本好雄, 青木正弘, 織田達男, 辻本浩輔, 長田宏 司, 藤井寿一, 清水 勝：本院における輸血関連 (TA)-GVHD 予防のための輸血用血液への放射 線照射の経緯と現状. 日本輸血学会雑誌, $45: 180$, 1997. 